\title{
Aural foreign body in situ for 9 years mimicking impacted wax
}

\author{
Thomas Geyton, Charles Holden, Simon Watts
}

Department of ENT surgery, Brighton and Sussex University Hospitals NHS Trust, Brighton, UK

\section{Correspondence to Dr Thomas Geyton, Geyton@gmail.com}

Accepted 16 March 2018

\section{DESCRIPTION}

An 11-year-old girl presented following a longstanding history of unilateral tinnitus, aural fullness and discomfort. She had seen multiple primary care doctors and repeatedly been diagnosed with unilaterally impacted wax. While on holiday in Bali she unfortunately suffered from tonsillitis and received a full ear, nose and throat (ENT) examination. A wax-coloured bead was identified in her external auditory canal (figures 1 and 2). On return to the UK she attended our ENT outpatient department for an uneventful removal of the foreign body under general anaesthetic.

On reflection, the child's mother recalled witnessing the child placing the bead in her ear at the age of 2. Fortunately, due to the inert nature of this foreign body no lasting damage was caused.

Organic foreign bodies may cause significant inflammation through activation of the immune system. A button battery in the ear canal may cause permanent damage through electrolysis and hydroxide formation. ${ }^{1}$

Children commonly present with foreign bodies in their ears, noses and throats. Where there is any uncertainty with regard to the cause of symptoms

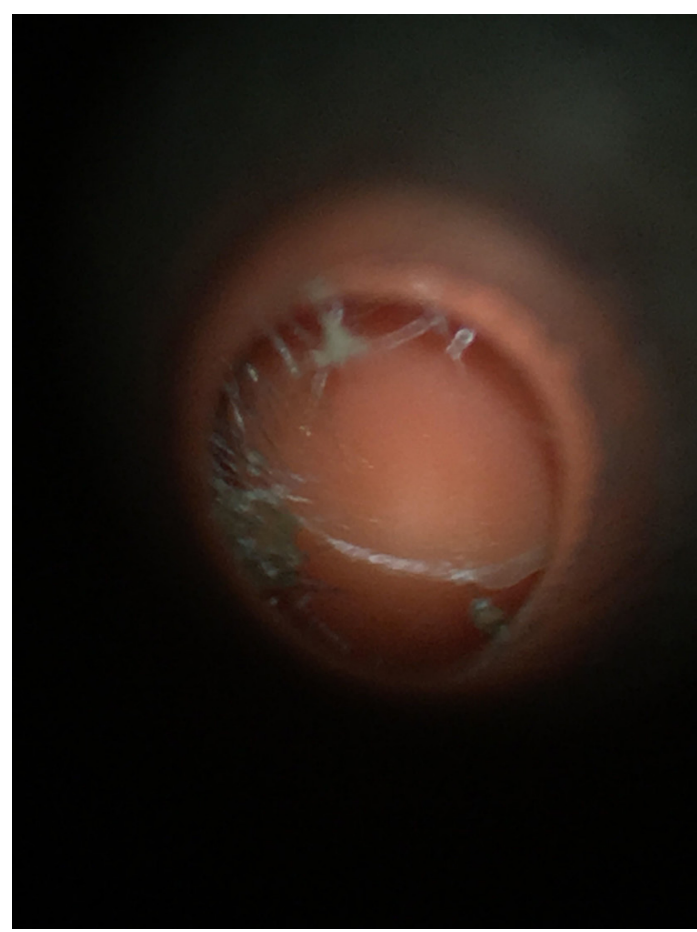

Figure 1 View of foreign body in situ mimicking impacted wax.

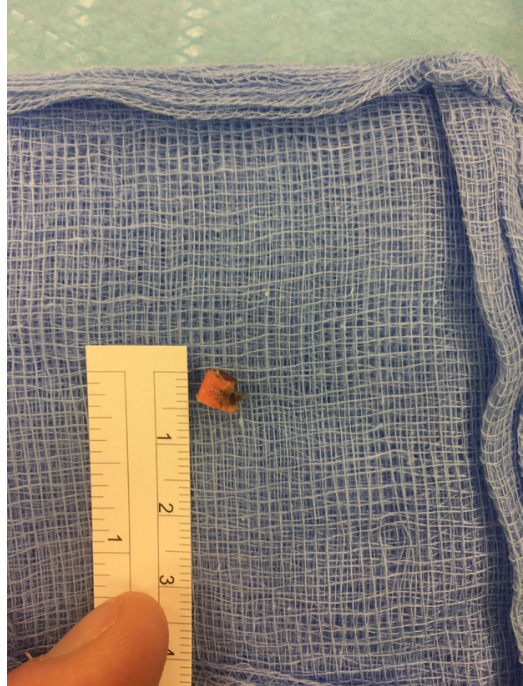

Figure 2 Foreign body following removal.

a specialist opinion is indicated. Persistent discomfort or otalgia may indicate the presence of an aural foreign body. Foreign bodies are usually easily removed in clinics or under a general anaesthetic with complete resolution of symptoms.

\section{Learning points}

- If there is uncertainty regarding the diagnosis of an aural foreign body, a referral to ear, nose and throat specialist should be considered.

- Where a foreign body is suspected, prompt examination is required to exclude the presence of a button battery.

- Inert substances in the ear canal may be removed in an elective setting.

Contributors TG and $\mathrm{CH}$ were both in theatre for the operation. They cowrote the article. SW was the supervising consultant.

Funding The authors have not declared a specific grant for this research from any funding agency in the public, commercial or not-for-profit sectors.

Competing interests None declared.

Patient consent Parental/guardian consent obtained.

Provenance and peer review Not commissioned; externally peer reviewed.

(C) BMJ Publishing Group Ltd (unless otherwise stated in the text of the article) 2018. All rights reserved. No commercial use is permitted unless otherwise expressly granted.

\section{REFERENCE}

1 Lin VY, Daniel SJ, Papsin BC. Button batteries in the ear, nose and upper aerodigestive tract. Int J Pediatr Otorhinolaryngol 2004:68:473-9. 
Copyright 2018 BMJ Publishing Group. All rights reserved. For permission to reuse any of this content visit http://group.bmj.com/group/rights-licensing/permissions.

BMJ Case Report Fellows may re-use this article for personal use and teaching without any further permission.

Become a Fellow of BMJ Case Reports today and you can:

- Submit as many cases as you like

- Enjoy fast sympathetic peer review and rapid publication of accepted articles

Access all the published articles

- Re-use any of the published material for personal use and teaching without further permission

For information on Institutional Fellowships contact consortiasales@bmjgroup.com

Visit casereports.bmj.com for more articles like this and to become a Fellow 